\title{
Phonological Development and Phonological Processes in the Speech of an English-Arabic Bilin- gual Child
}

Hana Asaad Daana*

Department of English Language and Literature, Princess Alia University College, Al-Balqa Applied University, Amman, Jordan Corresponding Author: Hana Asaad Daana, E-mail hana97us@yahoo.com

\begin{abstract}
ARTICLE INFO
Article history

Received: March 11, 2018

Accepted: May 08, 2018

Published: September 01,

2018 Volume: 7 Issue: 5

Advance access: July 2018

Conflicts of interest:

None Funding: None

ABSTRACT

This research traces the phonological development and the phonological processes in the speech of a bilingual child acquiring Jordanian Arabic and English. This trace is carried out through a thorough description of the phonological development of segments in Jordanian Arabic and English. It is also carried out through discussing the phonological processes resorted to by the child in order to simplify the production of segments in both languages. This study is the first of its kind to compare and contrast phonological processes in the speech of a bilingual child whose two first languages descend from two different linguistic families. The study also scrutinizes evidence of any influence of one language over the other. Evidence for either the Separate Development Hypothesis or the Fusion Hypothesis is also investigated. The data used in this paper are collected by the author from her own child acquiring Arabic and English simultaneously between the ages of 7 and 20 months. The child's sound segment development showed consistency with universal trends. Phonological processes such as regressive and progressive assimilation, substitution and metathesis were found in the child's production of English and Arabic sounds. The study provides limited evidence for the occurrence of interlanguage interference. On the other hand, the study provides strong supportive evidence for the Separate Development Hypothesis.
\end{abstract}

Key words: Phonological Development, Simultaneous Bilingualism, Phonological Processes, Separate Development Hypothesis, Fusion Hypothesis

\section{INTRODUCTION}

Several studies have been conducted to trace phonological development and phonological processes in the speech of monolingual children (Daana 2009; Hume 1998; Ingram 1986/1981/1973; Jakobson 1971; Johnson and Reimers 2010; Kohler 1990; Stempe 1969; Steriade 2001; Younis 2008) as well as bilingual children (Adnyani and Pastika 2016; Celce-Murica 1978; De Houwer 1990; Deuchar and Quay 1998; Genesee 1989; Hulk and Van der Lenden 1996; Johnson and Lancaster 1998; Leopold 1978/1970; Lieven 2010; Muller 1998; Nicoladis 1998; Paradis 1996; Redlinger and Park 1980; Vogel 1975; Volterra and Taeschner 1978; Yip and Mathews 2007; Yip 2013; Daana 2017a; Daana 2017b; Daana and Khrais 2018). Very few studies have investigated phonological development in the speech of monolingual Arab children -Jordanian children in specific- (Daana 2009; Al-Amayreh 1994; Omar 1973; Salim and Mehawesh 2014) none of which has tackled phonological processes in the speech of those monolingual Arab children. To the author's knowledge, no research has been conducted to investigate the phonological development of a bilingual child acquiring English and Arabic simultaneously except for (Daana 2017a; Daana 2017b; Daana and
Khrais 2018). However, none of these research has traced the phonological processes in the speech of their subjects. Hence, in addition to tracing the phonological development of Arabic and English, the main aim of this study is to present the field of bilingualism with data sets from English and Arabic illustrating the phonological processes resorted to by a bilingual child acquiring Jordanian Arabic and English.

The second aim of the study is to show further evidence for either the Fusion Hypothesis or the Separate Development Hypothesis. One of the major concerns of research on language development of children acquiring two first languages is whether these simultaneous acquirers pass through a stage when their two languages operate from one system or whether they handle each language separately right from birth. Two poles of the continuum represent two different hypotheses proposed by different researchers. Leopold (1978) proposed the Fusion Hypothesis which assumes that bilingual children develop one unified linguistic system through which two languages operate right from the beginning. That is to say the child's system is undifferentiated (Leopold 1970/1978; Vogel 1975; Celce-Muricia 1978; Redlinger and Park 1980; Volterra and Taeschner 1978). Genesee (1989) called this the Unitary Language System Hypothesis (ULSH).

Published by Australian International Academic Centre PTY.LTD.

Copyright (c) the author(s). This is an open access article under CC BY license (https://creativecommons.org/licenses/by/4.0/) http://dx.doi.org/10.7575/aiac.ijalel.v.7n.5p.197 
Far on the other end of the continuum, De Houwer (1990) proposed the Separate Development Hypothesis which assumes that bilingual children develop two separate and independent linguistic systems right from the beginning of the acquisition process. Several studies supported this hypothesis (Deuchar and Quay 1998; Nicoladis 1998; Ingram 1981; Johnson and Lancaster 1998, Paradis 1996; Schnitzer and Krasinski 1996).

However, somewhere in between, a third group of researchers suggested that bilingual children start the acquisition process with a single linguistic system which splits into two different systems at around the age of two or three. In other words, their linguistic system is partially differentiated (Schnitzer and Krasinski 1994).

The third aim of this study is to detect evidence of language transfer of one language over the other in the production of this particular child. The issue that has been under investigation for long is the influence of one language system over the other in bilingual children acquiring two first languages simultaneously. This influence can be experienced when one of the bilingual child's languages is more dominant than the other. This language influence might be in the form of either transform or interference of the dominant language (Yip and Mathew 2007; Yip 2013; Adnyani and Pastika 2016).

This influence does not necessarily take place at every linguistic level. Only one aspect of the dominant language may be transferred to the dominated language. In other words, the influence may be at the syntactic level (Hulk and van der Linden 1996; Muller 1998), or at the phonological level (Celce-Murcia 1978; Leopold 1970; Vogel 1975; Deuchar and Clark 1996; Ingram 1986). This study is limited to the phonological aspect of the child's production.

\section{The Aims of the Study}

This study is conducted to achieve the following objectives:

1- The study aims at tracing the development of sound segments of English and Jordanian Arabic in the speech of a child exposed to two typologically different languages.

2- It aims at describing the different phonological processes found in the child's early English and Arabic words.

3- Since the child's dominant language was Arabic and then shifted to English by the age of 15 months, the study also aims at investigating any kind of interference or transfer of the Arabic sound system on the English sound system or vice versa.

4- The study aims at providing further evidence for either the Fusion Hypothesis or the Separate Development Hypothesis.

\section{METHOD}

The subject of this study was born in the United Kingdom to a mother who was a $\mathrm{PhD}$ candidate majoring in Language Acquisition at the time. The native language of the subject's parents was a form of Jordanian Arabic used in the capital city of Jordan-Ammani Arabic, and they both were fluent in English.
The child spent the first 15 months at home with his grandmother who flew to the UK to assist looking after the child while his parents were busy working (the father) and studying (the mother). So throughout the first 15 months the child was mainly exposed to Arabic with some English from the mother. This might explain the dominancy of the Arabic language in the very early stages of the child's production. At the age of 15 months, when his grandmother had to return to Jordan, the child was sent to daycare nurseries and then preschool nurseries where he was exposed to English for a long time on daily basis. At home, the subject's father used only Arabic while his mother used more English than Arabic to communicate with him. In addition, the child used to watch cartoon movies on the English national channels. His limited exposure to Arabic and his long-hour exposure to the English language made of English the child's dominant and preferable language. This preference of a language over another by children raised bilingually has been attested by Lieven 2010 .

\section{Data Collection}

Data analyzed in this study were collected by the subject's mother the author of this study. Data collection took the form of audio recordings of spontaneous speech between the mother and the child in both languages- English and Arabic. The subject's mother also conducted occasional formal sessions showing the child pictures and asking him to name what he could see. The child was also asked to point to the pictures named by the researcher in order to check the child's comprehension in both languages. These sessions were con-ducted over the first five years of the child's age on daily basis. Each session lasted for about 45 minutes. The sessions were audio recorded at the child's home in his room. No other person was present during the sessions. Audio recordings were phonetically transcribed on site. They were chronologically saved in computer files. Each file consisted of: the child's production, the adults form, number of times the utterance was repeated in the session, and some details about the context if required. In addition, the glossary of the Arabic production was included. The transcription of data was checked by another PhD candidate who happened to be preparing for his thesis in Phonology.

\section{English and Arabic Sound Systems}

English and Arabic are two genetically different languages as they descended from two different origins. Some particular Arabic consonants do not occur in English these include: the dental, emphatic voiced and voiceless sounds /D/and /T/ respectively, alveolar emphatic fricative /S/, uvular voiced and voiceless fricatives $/ \gamma /$ and $/ \chi /$, pharyngeal voiced and voiceless fricatives $/ \mathrm{S} /$ and $/ \mathrm{h} /$, and the glottal stop / $/$. Some Arabic vowels do not occur in English. These are: the mid-low front long /e:/and the low front long vowel /a:/.

On the other hand, there are some English consonants that do not occur in the form of Arabic under investigation. These are: / $/$, $\theta, \mathrm{y}, \mathrm{d}, \mathrm{t}, \mathrm{g}$, and $\mathrm{v} /$. 
Vowels that occur in English but do not occur in Arabic are: / $\Lambda, 0$, ə/ and the low back long/a:/. All English diphthongs do not occur in the form of Arabic under study.

\section{RESULTS AND DISCUSSION}

\section{The Development of Consonants and Vowels in the Child's Speech.}

For the purpose of this study, only the phonetic data collected between the ages of 7 months and 20 months were represented and analyzed. The child in this study, however, experienced early production of linguistic sounds. Before the age of 7 months, the child's production was in the form of babbling and crying. These sounds had no personal nor non-personal referents. His linguistic stage was marked at around 7 months when he started using syllabic utterances such as [a a], [baba] and [papa]. By the age of 20 months, the child's production started to consist of two-word utterances. Hence, data collected between the ages of 7 and 20 months were analyzed for the purpose of this study.

The low front /a/ vowel was the first to occur in context at the age of 7 months. This vowel was accompanied by the first consonants to appear. Bilabial stops $/ \mathrm{b} /$ and $/ \mathrm{p} /$ were used together with /a/. [ba ba] stood for the word bye bye. This was used accompanied by waving his hand and crying when he saw someone leaving. Two months later, [pa pa] and [ta ta] were used by the child whenever he was trying to convey a message to his parents. He used such utterances while jumping and pointing excitedly to the cartoon movies on the television. He used them while he was trying to reach to his toys, water or milk. One month later, three more consonants appeared. These new consonants were $/ \mathrm{d} /, / \mathrm{m} /$ and $/ \mathrm{n} /$. They were also accompanied by $/ \mathrm{a} / \mathrm{as}$ in [da da] which was also used to point to something around. [mama] or [ma] was used to address his mother. [papa] and/or [baba] was used to address his father. /n/occurred in /nan/when the child was trying to ask for food. This sequence of consonantal occurrence was proposed by Jakobson (1971) in his Opposition Theory. It was also attested in Daana's study (2017a). One month later, at the age of 11 months /f/was used in [fafa] the child's father's name Fawaz, and /h/was used in the child's mother's name. It is not easy to decide whether the sounds the child had been producing so far were English or Arabic sounds. This is because these sounds are phonemes shared by both languages. Besides, they were not given in linguistic contexts. They were used accompanied by body movements, rather. In addition to the frequent use of the above stated utterances, the child's vocabulary mounted to 21 new Arabic words with the appearance of other new sounds such as /?, $\mathrm{T} /$ and new front vowels /e, e:/at the age of 14 months. The child started producing words such as [?ana] 'I', [?ana] for his mother's name, [?anna] for /mu $\theta \mathrm{nna} /$ his Jordanian friend's name, [?anna] for/stanna/ 'you wait', [ba] for /bai/ bye and for /bah/ 'finished', [ma] for /mal/ 'water',[ne:]for /tne:n/ 'two', [tate] for /tla:te/ 'three', [TaTa] and [baTa] for /baTa:Ta/ 'potatoes'. He also produced [na:] and [ma:m] for /na:m/ 'sleep' when he wanted to go to bed, or when he found his father sleeping, [ne:na] /we:nha/ was used when he asked for something he could not see 'where is it?', and [meme] instead of /lahme/ for 'meat'. The only mid-low back vowel that newly occurred at this age was /っ:/ in [bo:] for /bo:T/ 'trainers' which was frequently used when he wanted to put his trainers on to go out.

At the age of 15 months, velar $/ \mathrm{k} /$, uvular $/ \chi /$ and coronal fricatives $/ \int$, s/ occurred in addition to the consonants stated above. The sequence of sound acquisition in which the emergence of stops precedes the fricatives corresponds to Jakobson's Opposition Theory (1971). The appearance of the velar sounds after bilabial and dental and/or alveolar sounds is in line with the law of irreversible solidarity which assumes that the acquisition of velar sounds indicates the acquisition of labial and dental and/or alveolar sounds (Adnyani and Pastika 2016).

More back vowels were developed at this stage /o, $v, \mathrm{u}: /$. Central $/ \Lambda /$ and long front /i:/ also occurred. These new sounds appeared in the following 5 new Arabic words: [teta] was used for 'grandma', , [taku] /Sukran/ 'thank you', [nunu] 'childish word

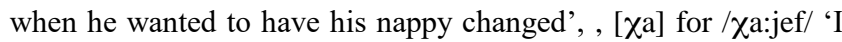
am scared' and [ke $\chi$ for 'dirty'. In addition, the first 5 English words produced so far were [berbi] baby, [ $\left.\int \varepsilon \mathrm{s}\right]$ chips, $\left[\mathrm{k}^{\mathrm{j}} \supset \mathrm{k}^{\mathrm{j}}\right]$ cake, [ $\Lambda \mathrm{n}]$ one, [tu:] two, [?i:] three. The last three words were used by the child while he was trying to count with his favourite cartoon film on the television. In / $\theta$ ri:/the child replaced the cluster in the onset position with / $/ \mathrm{l} / \mathrm{i} \mathrm{i}]$. In /keIk/the child replaced the front diphthong /eI/with a back mid-low / $/$. It is worth noting that at this age the child started to be sent to the university day-care nursery and used to spend a long time there (6 to 7 hours on daily basis). Hence, an apparent development in the child's English had started to be detected.

At the age of 17 months, the Arabic pharyngeal /S/, the English velar nasal $/ \mathrm{y} /$ and front short /I/ developed. The appearance of Arabic Arabic /S/ was restricted to three words [sa:Ya] 'watch', [Yammo] 'uncle', and [taYa] 'you come'. The English English /y/ however, was restricted to the word [n॰:nın] for morning.

At the age of 18 months, the Arabic pharyngeal fricative /S/ was used in [ba:S] 'bus' which was also produced as [baba] occasionally. English /æ/ appeared in [kæt]. It might be too early, at this stage, to attribute the emergence of the English /v/, which does not exist in Arabic, in the Arabic word [?awve] /Rahwe/ 'coffee' to the influence of English. But it is noticed that the dominancy of one language over the other had started to shift in favour of English. Consequently, Arabic ///started to be occasionally replaced by / $/$ / in /Yammo/ 'uncle'. This might be a sign of the English taking over from the Arabic and becoming the preferred language resulted from the long exposure to English.

At this age, 18 months, /f/was produced more often in Arabic and English words in different positions. It was used in onset position [fi:], [fo:] and [farn] for English three, four and five respectively. It was also used in [fawa] for English flower, and in [fofo] for Fawaz his father's name. In Arabic, it was used in [f Inunu] the childish word for 'I need to go to the toilet' and in the word [?aff] /Raraf/ 'disgusting'. 
The central liquid /r/was replaced by /v/ in [væbit] rabbit. This age also marked the emergence of the first English diphthong /aI/ in [faI] for five and [kaI] for sky.

A clear rise in the child's English vocabulary was witnessed at the age of 19 months due to the longer exposure to English compared to the exposure to Arabic. English /z/ appeared for the first time in [ka:z] cars [nu:z] nose. English /1/was replaced by / $/$ in [æpu] apple and [s\&ku] circle. However, it was replaced by /j/ or /w/in onset position [jet] let and [wuk] look. English /g/ appeared for the first time in [عgk] egg. English central /3:/ appeared for the first time in [b3:d] bird.

At the age of 20 months, the child continuously produced a larger number of English and Arabic words. However his production of English words was five times more than his production of Arabic words. English diphthongs started to appear at this age namely /ei/ in [berbi] baby and [neIm] name, /ai/ in [kaI] sky and [haI] high, /av/ in [aut] out and [auts] ouch and /ov/ in [nəu] snow and [nəu] no. The development of the sound systems of both languages continued gradually. However, it cannot be assumed that this development continued independently. This can be inferred from the use of English/v/sound in the Arabic word [?awve] /Rahwe/ 'coffee' to replace Arabic /h/. This replacement was repeated several times over a long period of time. This dependent consonantal development in both languages can also be inferred from the gradual elimination of Arabic/S/ and its replacement with $/ 2 /$. The development of the child's consonants and vowels is summarized in Table 1.

As can be inferred from Table 1, the child had acquired consonants which exist in both languages as well as consonants which exist in either language. The first 8 consonants which are shared by both languages were used in Arabic words. Two Arabic consonants which do not exist in English were also acquired early /R, T/. Amongst the first four vowels which were acquired early, three were shared by both languages but were only used in Arabic words. The fourth was exclusive to Arabic/e:/.

Table 1. The development of the child's consonants and vowels

\begin{tabular}{|c|c|c|}
\hline Age & Consonants & Vowels \\
\hline 7 months & $\mathrm{pb}$ & $\mathrm{a}$ \\
\hline 10 months & $\mathrm{dmnt}$ & \\
\hline 11 months & $\mathrm{fh}$ & \\
\hline \multicolumn{3}{|l|}{12 months } \\
\hline \multicolumn{3}{|l|}{13 months } \\
\hline 14 months & $? \mathrm{~T}$ & $\varepsilon$ e e: $\supset:$ \\
\hline 15 months & $\mathrm{k} \chi \int \mathrm{s}$ & $\supset \cup \mathrm{u}: \Lambda \mathrm{i}:$ \\
\hline 16 months & S $\mathrm{J}$ & I \\
\hline 17 months & $\mathrm{S}$ & $æ$ \\
\hline 18 months & $\mathrm{f}$ & a I \\
\hline 19 months & $\mathrm{z} \mathrm{j} \mathrm{g}$ & 3: a: \\
\hline 20 months & $\mathrm{w}$ & e I $\mathrm{a} U$ əu \\
\hline
\end{tabular}

The child's tendency of using these sounds whether they are shared by both languages or are exclusive to Arabic in Arabic words and in Arabic context stemmed from the dominancy of Arabic. This is because the child used to spend a long time with his grandmother. When the child's grandmother returned to Jordan, sounds exclusive to either language continued to appear with more occurrences of English sounds and English words in English context. This took place as a result of sending the child to the university day-care nursery and then to a preschool nursery. Hence, the child started to spend longer time in British environment with English surrounding him. Sounds that are exclusive to Arabic such as $/ \chi, \mathrm{S}, \mathrm{S} /$ started to occur along with sounds that are exclusive to English such as /v, y, g/. Exclusive English diphthongs were acquired the latest. Given that the child's English input outnumbered his Arabic input, it became clear that the child was in favour of English at this age. The shift in the dominancy of languages is obvious in the child's constant replacement of Arabic/// with the glottal / $/$. The child replaced Arabic / / / with / $/$ /as any native speaker of English would do when learning how to pronounce this Arabic sound. Arabic/S/ reappeared only when the child went back to his home country after the age of 5 years.

It is necessary to point out that the form of British English to which the child was exposed at that time in that town replaces /t/with / $/$ /. In other words glottal / $/$ /does exist in the British accent the child was exposed to. This English accent replaces /t/between vowels or in coda position with/2/. Accordingly, the child started replacing English /t/ with/2/. However, he did not replace Arabic/t/with/1/. This is evidence that this child was aware of the different phonological systems of both languages and was acting accordingly.

Throughout the course of acquisition the child used some phonological processes in order to simplify the production of some sounds in some situations and to replace sounds which had not been acquired yet such as/l, r/in Arabic and English.

\section{The Child's Data and Phonological Processes}

So far, it is obvious that the child's phonological system in each language had developed gradually and significantly. By virtue of the fact that Arabic input was dominant as compared to English input, documentation of the child's production in Arabic was more than that of English through the first 7 to 15 months of the child's age. Once the child was sent to a day-care nursery, then to a preschool nursery, English input outnumbered Arabic input. This had led to a gradual takeover of English and therefore the documentation of the child's English production was greater than that of the Arabic.

Along the course of language acquisition the child used phonological processes to simplify the production of certain sounds in both languages. These phonological processes have been attested in the literature of language acquisition (Stempe 1969; Ingram 1981; Johnson and Reimers 2010). Assimilation, metathesis and substitution are the main phonological processes to which children resort in order to simplify the adults form and in order to make it match their perceptual and/or productive capacities (Stempe 1969; Ingram 1981; Daana 2009; Johnson and Reimers 2010). 
The subject in this study used these phonological processes in his attempt to simplify English and Arabic utterances. This part of the study sheds some light on assimilation, substitution and metathesis used by the child to simplify his English and Arabic production.

\section{Assimilation process}

Assimilation is the process when one segment borrows a feature from an adjacent segment. It could be done either progressively or regressively. When the target segment precedes the triggering segment, regressive assimilation is witnessed. It is also referred to as right-to-left assimilation. When the target segment follows the triggering segment, progressive assimilation is witnessed. Progressive assimilation is also referred to as left-to-right assimilation. Assimilation is one of the phonological processes to which the child in this study resorted in both languages. The reason the child resorted to assimilation could be the ease of articulation. However, Steriade (2001) posited that the factor which determines assimilation can also be perceptual since the perceived similarity between the two segments triggers assimilation.

\section{Regressive assimilation}

Most of the assimilation instances in the child's data were regressive. The child's regressive assimilation processes underwent different forms.

a) Consonantal Harmony

The types of consonantal harmony can be classified as follows:

i- Nasal Harmony

Nasal harmony is one of the assimilation methods that has taken place in the child's speech. It has also been found in the speech of other bilingual children. In Adnyani and Pastika (2016), nasal harmony was found in the speech of their Indonesian-German bilingual subject. Their subject nasalized her initial bilabial stops. In this study, the application of nasal harmony was not restricted to initial bilabial stops.

Initial velar glide/w/was nasalized when followed by a nasal. Initial alveolar sounds/l, $t, \mathrm{~s} /$ were also nasalized when followed by a nasal Table 2 .

Although Kohler (1990) depicts that nasals are more likely to assimilate than other sounds, in the subject's production in this study, nasal sounds were found to be triggers rather than targets.

ii- POA Harmony

Regressive assimilation in terms of place of articulation was witnessed in the child's data. A target sound borrowed the POA feature from the triggering sound. The alveolar /n/ in /na:m / sleep' was assimilated to the following bilabial $[\mathrm{ma}: \mathrm{m}]$. The glottal $/ \mathrm{h} /$ in /Rahwe/'coffee' was closely assimilated to the labiovelar /w/and produced as labiodental [v]. The glottal /h/ in /hawa/ 'air' was assimilated to the following velar [wawa]. Bilabial nasal $/ \mathrm{m} /$ in morning changed into alveolar nasal /n/ [no:nıy].
Alveolar/r/in rabbit was assimilated to the following bilabial [bæbit]. This utterance was also -produced as [betet] in which bilabial /b/ became Alveolar /t/. Alveolar/t/in tiger became velar $/ \mathrm{k} /$ [kækə]. This can be summarized in Table 3.

This form of assimilation resulted in mapping the place of articulation of a consonant to the consonant preceding it to make the production easier.

iii- Voicing

Table 4 shows the third form of consonantal regressive assimilation that was detected in the child's data,

Table 2. Nasal harmony

\begin{tabular}{|c|c|c|c|}
\hline Age & Words & Child's production & Glossary \\
\hline \multicolumn{4}{|l|}{ Arabic } \\
\hline \multirow[t]{2}{*}{$\begin{array}{l}14 \\
\text { months }\end{array}$} & /we:nha/ & [ne: na] & $\begin{array}{l}\text { where is } \\
\text { it }(F) ?\end{array}$ \\
\hline & /lahme/ & [meme] & meat \\
\hline $\begin{array}{l}17 \\
\text { months }\end{array}$ & /RaStıni/ & [nIni] & give me \\
\hline English & & & \\
\hline $\begin{array}{l}19 \\
\text { months }\end{array}$ & ten & [nen] & \\
\hline 20 & seven & [nen] & \\
\hline months & balloon & [bænu:n] & \\
\hline
\end{tabular}

Table 3. POA harmony

\begin{tabular}{|c|c|c|c|}
\hline Age & Words & Child's production & Glossary \\
\hline \multicolumn{4}{|l|}{ Arabic } \\
\hline $\begin{array}{l}14 \\
\text { months }\end{array}$ & /na:m/ & [ma:m] & sleep \\
\hline $\begin{array}{l}17 \\
\text { months }\end{array}$ & /Rahwe/ & [?awve] & coffee \\
\hline $\begin{array}{l}20 \\
\text { months }\end{array}$ & /hawa/ & [wawa] & air \\
\hline English & & & \\
\hline $\begin{array}{l}16 \\
\text { months }\end{array}$ & morning & [no:nın] & \\
\hline 19 & rabbit & [bæbit] & \\
\hline months & & [bæbit] & \\
\hline $\begin{array}{l}20 \\
\text { months }\end{array}$ & tiger & [kækə] & \\
\hline
\end{tabular}

Table 4. Voicing

\begin{tabular}{llll}
\hline Age & Words & Child's production & Glossary \\
\hline Arabic & & & \\
17 & /Rahwe/ & [Rawve] & coffee \\
months & & & \\
English & & & \\
20 & spoon & [bu:n] & \\
months & & & \\
\hline
\end{tabular}


, prevocalic voicing in which the [+voiced] feature spread regressively from the consonant in coda position to the consonant in onset position. This form could be detected in the monosyllabic word spoon which was produced as [bu:n]. It also spread from the consonant in onset position to the consonant in coda position in disyllabic/Rahwe/.

b) Vowel Harmony

Three examples of regressive vowel harmony were detected in the child's data. In rabbit, which underwent consonantal harmony as stated above, the feature [+high] of /I/in the second syllable spread to the first syllable and replaced the low $/ æ /$. However, /I/in both syllables was slightly lowered to sound as /e/and the word was produced as [betet]. The second example of vowel harmony was found in the Arabic word /lahme/ 'meat' which was produced as /meme/. However, the mid-high /I/ in the Arabic word / $\mathrm{ISSa}$ / 'story' was lowered to map with the low/a/vowel in the second syllable resulting in [?aSSa]. This is shown in Table 5

c) Vowel- Consonant Harmony

In this kind of regressive assimilation the vowel was the trigger and the preceding consonant was the target. Alveolar liquid /1/was produced as [j] when followed by a front vowel. However, it was produced as $[\mathrm{w}]$ when followed by a back vowel. This form of assimilation exclusively appeared in the child's production of English /1/. This is illustrated in Table 6.

\section{Progressive assimilation}

Very few utterances underwent progressive or left-to-right assimilation. Only consonantal harmony was detected in the child's data. No examples of progressively assimilated vowels were detected in the child's data.

a) Consonantal Progressive Harmony

This form of progressive assimilation can be classified into two types: POA harmony and devoicing.

Table 5. Vowel harmony

\begin{tabular}{|c|c|c|c|}
\hline Age & Words & Child's production & Glossary \\
\hline Arabic & & & \\
\hline $\begin{array}{l}14 \\
\text { months }\end{array}$ & /laћme/ & [meme] & meat \\
\hline $\begin{array}{l}18 \\
\text { months }\end{array}$ & /PISSa/ & [?aSSa] & story \\
\hline $\begin{array}{l}\text { English } \\
19 \\
\text { months }\end{array}$ & rabbit & [betet] & \\
\hline
\end{tabular}

Table 6. Vowel - Consonant Harmony

\begin{tabular}{llll}
\hline Age & Words & Child's production & Glossary \\
\hline English & & \\
20 & look & {$[\mathrm{wvk}]$} \\
months & let & {$[\mathrm{jet}]$} & \\
\hline
\end{tabular}

\section{i- POA Harmony}

POA harmony was found in the production of only one Arabic word and one English word as is exemplified in Table 7. The alveolar $/ \mathrm{n} /$ in pen was labialized and produced as [pem]; whereas, the bilabial $/ \mathrm{b} /$ in $/ \mathrm{kalb} / \mathrm{dog}$ was velarized and the word was produced as [kak].

ii- Devoicing

The second form of progressive assimilation which was detected in the child's data was postvocalic de-voicing. The consonant in coda position borrowed the feature [-voiced] from the consonant in onset position. This is illustrated in Table 8 . The voiced velar $\mathrm{h} / \mathrm{f}$ was devoiced in tongue which was produced as [tek]. The feature [- voiced] spread to affect the voiced velar/g/and was replaced by $/ \mathrm{k} /$ in tiger. In spoon, the alveolar $/ \mathrm{n} /$ was devoiced and velarized thus produced as [pu:k].

\section{Substitution process}

Substitution is one of the phonological processes children usually resort to when the sounds are difficult for them to articulate. The substitution process can be traced and explained by mapping the child's output to the child's input. It takes different forms, stopping, gliding and fronting. The subject in this study resorted to the three forms in both languages.

\section{Stopping}

Stopping is a phonological process in which the child in this study replaced a fricative sound with a stop. The child's data showed that fricatives were stopped regardless of their position in the syllable; that is to say, the child replaced fricatives with stops in onset position as well as in coda position.

Table 7. POA harmony

\begin{tabular}{llll}
\hline Age & Words & Child's production & Glossary \\
\hline English & & & \\
20 & pen & {$[\mathrm{p} \varepsilon \mathrm{m}]$} & \\
months & & & \\
$\begin{array}{l}\text { Arabic } \\
20\end{array}$ & & & $\operatorname{dog}$ \\
months & & {$[\mathrm{kak}]$} & \\
\hline
\end{tabular}

Table 8. Devoicing

\begin{tabular}{llll}
\hline Age & Words & Child's production & Glossary \\
\hline $\begin{array}{l}\text { English } \\
20\end{array}$ & tongue & {$[\mathrm{t \varepsilon k}]$} & \\
months & & \\
& tiger & {$[\mathrm{kæk} ə]$} & \\
& spoon & {$[\mathrm{pu}: \mathrm{k}]$} & \\
Arabic & & & $\mathrm{dog}$ \\
20 & $/ \mathrm{kalb} /$ & {$[\mathrm{kak}]$} & \\
months & & & \\
\hline
\end{tabular}


The child resorted to this process in both languages. The subject in this study replaced initial Arabic fricative / $\mathrm{J} /$ with [t] , and he replaced initial Arabic fricatives /f, h/ with [?]. In English, he replaced initial $/ \theta, \mathrm{f}, \mathrm{t} /$ with $[\mathrm{t}]$. He replaced initial English $/ \mathrm{v}, \mathrm{d} /$ with [d]. He also replaced final /v/ with [n] and final / $/$ with [t] and sometimes with [k]. This is illustrated in Table 9.

It is worth noting that the child replaced a voiced fricative with a voiced stop and a voiceless fricative with a voiceless stop. In other words, the child left the voiced and/or voiceless features intact.

\section{Gliding}

In this process, English /1/was replaced by the glide [j] and/or [w] depending on the position of this lateral sound. In onset position and before front vowels it was replaced by [j] whereas in onset position before a back vowel as well as in coda position it was replaced by the velar [w]. English /1/ in coda position was replaced by velar [w] by virtue of the velarized feature the dark /l/enjoys. Arabic /l/, however, was replaced by [j] regardless of its position or the surrounding sounds. English /r/was replaced by [w]. This shows that the child is aware of the feature [+rounded] which English $/ \mathrm{r} /$ enjoys. Arabic $/ \mathrm{r} / \mathrm{was}$ only replaced by [j] this is because Arabic trilled /r/ does not enjoy this roundness feature. This is another evidence that the child in this study was aware of the different phonological systems of both languages and was acting accordingly. This is illustrated in Table 10

It is of equal importance to point out that the English and Arabic lateral /l/ were substituted with the alveolar nasal [n] in

Table 9. Stopping

\begin{tabular}{|c|c|c|c|}
\hline Age & Words & Child's production & Glossary \\
\hline \multicolumn{4}{|l|}{ Arabic } \\
\hline $\begin{array}{l}15 \\
\text { months }\end{array}$ & / Jukran/ & [taku:] & thank you \\
\hline $\begin{array}{l}17 \\
\text { months }\end{array}$ & /Sammっ/ & [?ammo] & uncle \\
\hline \multirow{2}{*}{$\begin{array}{l}18 \\
\text { months }\end{array}$} & /habbe/ & [?abbe] & sweet \\
\hline & /hamma: m/ & [hammi: n] & toilet \\
\hline \multicolumn{4}{|l|}{ English } \\
\hline $\begin{array}{l}15 \\
\text { months }\end{array}$ & three & [?i:] & \\
\hline $\begin{array}{l}18 \\
\text { months }\end{array}$ & five & [fain] & \\
\hline \multirow{2}{*}{$\begin{array}{l}19 \\
\text { months }\end{array}$} & seven & [den] & \\
\hline & fish & {$\left[f_{\mathrm{ft}} \mathrm{t}\right]$} & \\
\hline \multirow{6}{*}{$\begin{array}{l}20 \\
\text { months }\end{array}$} & finger & [tigə] & \\
\hline & chair & [t3:] & \\
\hline & cheese & [ti:z] & \\
\hline & this & {$\left[\mathrm{dis}_{\mathrm{IS}}\right.$} & \\
\hline & that & [dæt] & \\
\hline & fish & {$\left[\mathrm{f}_{\mathrm{Ik}}\right]$} & \\
\hline
\end{tabular}

very few cases. This occasional substitution is consistent with the substitution performed by the child in Adnyani and Pastika (2016). Their subject replaced her German and Indonesian liquid /l/with the alveolar nasal [n]. This is illustrated in Table 11.

\section{Fronting}

The third substitution process is in the form of fronting in which a back consonant is replaced by a front consonant. Fronting was also evidenced in Adnyani and Pastika (2016) where their bilingual subject replaced back Indonesian and German sounds with front sounds. This is illustrated in Table 12.

Table 10. Gliding

\begin{tabular}{|c|c|c|c|}
\hline Age & Words & Child's production & Glossary \\
\hline \multicolumn{4}{|l|}{ Arabic } \\
\hline \multirow{4}{*}{$\begin{array}{l}20 \\
\text { months }\end{array}$} & /ra:ћ/ & [ja:ћ] & he went \\
\hline & /ru:h/ & [ju:h] & you go \\
\hline & /habel/ & [habej] & rope \\
\hline & /Razra?/ & [?azja?] & blue \\
\hline \multicolumn{4}{|l|}{ English } \\
\hline \multirow{2}{*}{$\begin{array}{l}18 \\
\text { months }\end{array}$} & look & [wuk] & \\
\hline & love & {$[j \Lambda v]$} & \\
\hline \multirow{6}{*}{$\begin{array}{l}20 \\
\text { months }\end{array}$} & let & [jet] & \\
\hline & run & {$[\mathrm{w} \wedge \mathrm{n}]$} & \\
\hline & room & [wu:m] & \\
\hline & slowly & [swo:ji] & \\
\hline & wall & [wo:w] & \\
\hline & apple & [æpuw] & \\
\hline \multicolumn{4}{|c|}{ Table 11. Nasals for Liquids } \\
\hline Age & Words & Child's production & Glossary \\
\hline \multicolumn{4}{|l|}{ English } \\
\hline $\begin{array}{l}20 \\
\text { months }\end{array}$ & look & [nuk] & \\
\hline \multicolumn{4}{|l|}{ Arabic } \\
\hline \multirow{2}{*}{$\begin{array}{l}20 \\
\text { months }\end{array}$} & $/$ lissa/ & [nissa] & not yet \\
\hline & /Ralam/ & [?aman] & pen \\
\hline
\end{tabular}

Table 12. Fronting

\begin{tabular}{llll}
\hline Age & Words & Child's production & Glossary \\
\hline $\begin{array}{l}\text { English } \\
18\end{array}$ & juice & [su:] & \\
$\begin{array}{l}\text { months } \\
20\end{array}$ & socks & [sots] & \\
months & six & [sits] & \\
$\begin{array}{l}\text { Arabic } \\
18\end{array}$ & /ka:se/ & [sa:te] & cup \\
months & & & \\
\hline
\end{tabular}


In English, the child chose to replace the voiceless velar $/ \mathrm{k} /$ with voiceless alveolar [t]. The child also fronted the English palate-alveolar /dg/and produced it as [s]. In Arabic, he chose to replace the voiceless velar $/ \mathrm{k} / \mathrm{with}$ voiceless alveolar $[\mathrm{t}]$ in /ka:se/ 'cup' as is shown in Table 12.

\section{Metathesis}

Metathesis is another phonological process children resort to throughout the course of language acquisition. It has been studied by different researchers such as Hyman 1975; Grunwell 1981; Younis 2008. Metathesis is a form of interchange or alternation of sounds within the boundary of a word (Crystal 2003; Hume 1998; Hartman and Stork 1976; Montler 1986). Hume (1998) depicted that in linear and non-linear phonological theories, metathesis is not considered a phonological rule-based approach. Hume further elaborated that it is not a distinct process. However, the development of the constraint-based theory of phonologyOptimality Theory, has succeeded dealing with the analysis of metathesis as a phonological process. In light of Optimality Theory, metathesis results from a violation of the constraint

LINEARITY which leads to a mismatch of the linear ordering of sounds between input and output (McCarthy and Prince 1999; Prince and Smolensky 2004).

The subject in the current study resorted to metathesis on very few occasions. There are eight instances in Arabic and four instances in English.

As can be inferred from Table 13, metathesis did not only involve adjacent segments as in [æks] ask. As a matter of fact, most of the utterances in the table above show the involvement of long-distance segment switching as in [ku:s] school and [daias] /Yadas/'lentils'.

Table 13. Metathesis

\begin{tabular}{|c|c|c|c|}
\hline Age & Words & Child's production & Glossary \\
\hline \multicolumn{4}{|l|}{ Arabic } \\
\hline \multirow{2}{*}{$\begin{array}{l}17 \\
\text { months }\end{array}$} & /Raktub/ & [?abut] & I write \\
\hline & /Rahwe/ & [?awve] & coffee \\
\hline $\begin{array}{l}18 \\
\text { months }\end{array}$ & /ka:se/ & [sa:te] & cup \\
\hline $\begin{array}{l}19 \\
\text { months }\end{array}$ & /kta:b/ & [ba:t] & book \\
\hline \multirow{4}{*}{$\begin{array}{l}20 \\
\text { months }\end{array}$} & /hilwe/ & [hiwle] & beautiful $(\mathrm{F})$ \\
\hline & //adas/ & [dafas] & lentils \\
\hline & /jana:1/ & [naja:j] & $\begin{array}{l}\text { the child's } \\
\text { name }\end{array}$ \\
\hline & /Ralam/ & [?aman] & pen \\
\hline English & & & \\
\hline $\begin{array}{l}16 \\
\text { months }\end{array}$ & good & [dog] & \\
\hline $\begin{array}{l}18 \\
\text { months }\end{array}$ & ask & [æks] & \\
\hline $\begin{array}{l}20 \\
\text { months }\end{array}$ & $\begin{array}{l}\text { school } \\
\text { computer }\end{array}$ & $\begin{array}{l}\text { [ku:s] } \\
\text { [buku:tə] }\end{array}$ & \\
\hline
\end{tabular}

This process affected consonants mainly; that is to say, there was only one utterance which underwent a change in the linear ordering between two vowels in adjacent syllables. The Arabic word / $\mathrm{skran/}$ was produced as [taku] by the child several times and for a reasonable period of time.

\section{CONCLUSION}

The study has come out with the following conclusions:

1- After presenting and investigating the data of the development of sounds in the production of the bilingual child whose two first languages are Arabic and English, it is noticed that the sequence of consonantal occurrence which started with/b/followed by $/ \mathrm{t} /$ and then $/ \mathrm{n} / \mathrm{is}$ in accordance with the sequence proposed by Jakobson (1971) in his Opposition Theory. This sequence was also detected in Daana's (2017a). The fact that the child's fricatives appeared after the stops in both languages is consistent with Jakobson's Opposition Theory. The appearance of the velar sounds after bilabial and dental and/or alveolar sounds corresponds with the law of irreversible solidarity.

2- Phonological sounds that exclusively exist in Arabic only appeared in Arabic words. No transfer of Arabic sounds such as $[\hbar, \Upsilon, \chi, \gamma]$ was witnessed in the production of English words. However, very limited evidence for examples that show interdependent development of both languages was found. A transfer of English glottal / / was constantly found to replace Arabic pharyngeal ///once English took over the dominancy in the child's output. This kind of replacement is typical of foreigners whose languages lack this sound when they learn Arabic. Furthermore, another transfer of English /v/ which does not exist in Arabic was continuously found to replace Arabic $/ \mathrm{h} /$. Even though the replacement of Arabic /h/with English / $/$ / was only found in the production of the word /Rahwe/ 'coffee' which was produced as [?awve], this replacement took place in a continuous and constant form over a long period of time. Transfer is a form of interdependent development of two languages in bilingual children which was attested in many bilingual language development studies (Genesee 2001; Yip and Matthews 2007). Hence, this study is another supportive evidence for Adnyani and Pastika's study (2016) as well as Genesee (2001) argument which entails that the languages of a bilingual child do not necessarily develop entirely interdependently nor do they develop entirely autonomously.

3- Regarding the Separate Development Theory, there are examples that show an independent development of the phonology of each language. Examples show that the child was aware of the phonological rules of each language and was acting accordingly. The replacement of English /1/with /w/ before back vowels and in coda positions but with /j/ before front vowels was continuously found in the child's English output. The exclusive application of this replacement to the English $/ 1 /$ can be attributed to the fact that this sound has the allophone velarized /l/- dark/l/. The fact that Arabic /1/ has no velarized form blocked the application of this assimilation process to Arabic /1/. 
Another example is the replacement of English /r/with /w/ by virtue of its [+rounded] feature. The fact that Arabic/r/does not enjoy this feature blocked its replacement with /w/and was replaced by [j] constantly. A third example is the replacement of English /t/with / / /influenced by the British dialect to which the child was exposed. This replacement did not take place in Arabic words, however.

4- In terms of the phonological processes experienced by the child in this study, regressive and progressive assimilation, substitution (stopping, gliding, and fronting), and metathesis were found in the production of English and Arabic words.

\section{RECOMMENDATIONS}

These conclusions only apply to this study. Future research needs to be conducted to determine whether other Arabic-English bilingual children develop phonological systems independently or interdependently. Further research also needs to be conducted to determine whether the phonological processes found in this study are apparent in the production of other Arabic-English bilingual children.

\section{REFERENCES}

Adnyani, N. and Pastika (2016). Phonological Development in the Early Speech of an Indonesian-German Bilingual Child. Research in Linguistics. 1 (3), 329-350. DOI: 10.13189/1ls.2017.050504.

Al-Amayreh, M. (1994). A Normative Study of the Acquisition of Consonant Sounds in Arabic. PhD Dissertation, University of Florida.

Celce-Murica, M. (1978). The Simultaneous Acquisition of

English and French in a two-year-Old Child. In E. Hatch (ed.).

Second Language Acquisition: A Book of Readings. 38-53.

Roeley. MA: Newbury House.

Crystal, D. (2003). A Dictionary of Linguistics and Phonetics. Blackwell Publication LTD: United Kingdom. DOI: 10.1108/09504120910969041.

Daana, H. (2017a). Phonological Development of an Arabic English Bilingual Child during the One-Word Stage. Linguistics and Literature Studies. 5 (5), 354-364. DOI: 10.13189/1ls.2017.050504.

Daana, H. (2017b). The Development of Coda Consonants in the Speech of a Bilingual Child: A Case Study. International Journal of Linguistics. 9 (5), 149-172. DOI: 10,5296/ijl.v9i5.11747.

Daana, H. (2009). The Development of Consonant Clusters, Stress and Plural Nouns in Jordanian Arabic Child Language. $\mathrm{PhD}$ Dissertation. University of Essex: UK.

Daana, H \& Khrais, S. (2018). The Acquisition of English and Arabic Onset Clusters: A Case Study. English Linguistics Research. 7 (1), 13-33. DOI: 10.5430/elr. v7n1p13.

De Houwer, A. (1990). Bilingual First Language Acquisition. Clevedon /Buffalo: Multilingual Matters.
Deuchar, M, and S. Quay. (1998). One vs. Two Systems in Early Bilingual Syntax: Two Versions of the Question.

Bilingualism: Language and Cognition. 13, 231-243. DOI: $10.1017 / \mathrm{S} 1366728998000376$.

Deuchar, M and Clark, A. (1996). Early Bilingual Acquisition of the Voicing Contrast in English and Spanish. Journal of

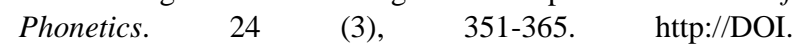
Org/10.1006/jpho.1996.0019.

Genesee, F. (2001). Bilingual First Language Acquisition: Exploring the Limits of the Language Faculty. Annual Review of Applied Linguistics. 153-170.

Genesee, F. (1989). Early Bilingual Development: One Language or Two? Journal of Child Language. 16, 161-180.

Grunwell, P. (1981). The Nature of Phonological Disability in Children. Academic Press, INC: London. https:// trove.nla.gov.au/version/32189383.

Hartman, R. and Stork, F. (1976). Dictionary of Language and Linguistics. Applied Science Publication LTD: London.

Hume, E. (1998). Metathesis in Phonological Theory: the Case of Leti. Lingua. 104, 147-186. DOI:10.1016/ S00243841(97)00031-4.

Hulk, A. \& Van der Lenden (1996). Language Mixing in a French-Dutch Bilingual Child. In E. Kellerman, B. Wel-tens \& T. Borgaerts (eds) Toegepaste Talawetenchap in Artikelen. $55,89-103$.

Hyman, L. (1975). Phonology: Theory and Analysis. Holt, Rinehart and Winston: U.S.A.

Ingram, D. (1986). Phonological Development: Production. In P. Fletcher and M. Garman (eds). Language Acquisition: Studies in First Language Development, 223-239.

Cambridge, UK: Cambridge University Press.

Ingram, D. (1981). Phonological patterns in the Speech of Young Children. In P. Fletcher and M. Garman (eds.),

Language Acquisition: Studies in First Language Development, 133-148. Cambridge: Cambridge University Press.

Ingram, D. (1973). Language Development in Children. In H. Fraser and W. R. O'Donnell (eds.), Applied Linguistics and the Teaching of English, 21-36. London: Longman Group Limited.

Jakobson, R. (1971). Studies on Child Language and Aphasia. The Haque: Mouton.

Johnson, C. E. and Lancaster, P. (1998). The Development of more than one Phonology: A Case Study of a NorwegianEnglish Bilingual Child. International Journal of Bilingualism. 2 (3), 265- 300.

Johnson, W. and Reimers, P. (2010). Patterns in Child Phonology. Edinburgh University Press: Edinburgh. DOI:10.1017/S0025100311000569.

Kohler, K. (1990). Segmental Reduction in Connected Speech: Phonological and Phonetic Explanations. In W. J. Hardcastle and A. Machal (eds.) Speech Production and Speech Modeling, 69-92. Kluwer Academic Publishers: Dordrecht.

Leopold, W. F. (1978). A Child's Learning of Two Languages. In E. M. Hatch (ed.), Second Language Acquisition: a Book of Readings, 23-32. Massachusetts: Newbury House Publishers. 
Leopold, W. F. (1970). Speech Development of a Bilingual Child: A Linguist's Record. Vols 1-4. Reprinted AMS: New York.

Lieven, E. (2010). Bilingual Language Acquisition. Human Development. 53(5), 256-263. DOI: 10.1159/000321285.

McCarthy, J. and Prince, A. (1999). Faithfulness and Identity in Prosodic Morphology. In Rene Kager, Harry Van der Hulst, and Wim Zonneveld (eds.) The Prosody- Morphology Interface, 218- 309. Cambridge University Press.

Montler, T. (1986). An Outline of the Morphology and Phonology of Saanich, North Straits Salish. Occasional Papers in Linguistics 4. Missoula, MT: University of Montana Linguistics Laboratory (Revised version of the author's $\mathrm{PhD}$ Dissertation University of Hawaii).

Muller, N. (1998). Transfer in Bilingual First Language Acquisition. Bilingualism, Language and Cognition. 1 (3), 151-172. Google Scholar.

Nicoladis, E. (1998). First Clues to the Existence of Two In-put Languages: Pragmatic and Lexical Differentiation in Bilingual Child. Bilingualism: Language and Cognition 1 Cambridge University Press 1. 105-116. DOI: 10.1017/S1366728998000236.

Omar, M. K. (1973). The Acquisition of Egyptian Arabic as a Native Language. Georgetown University Press: Washington DC.

Paradis, J. (1996). Phonological Differentiation in a Bilingual Child: Hidegard Revisited. In A Stringfellow, D. CanadaAmitay, E. Hughes, and A. Zukowski. (eds) BUCLD 20 Proceedings, 528-539. Somerville, MA: Cascadilla Press.

Prince, A. and Smolensky, P. (2004). Optimality Theory. Blackwell Publishing Company. UK. Google Scholar.

Redlinger, W. E. and Park, T. (1980). Language Mixing in Young Bilinguals. Journal of Child Language. 7, 337-352.
Salim, J., and Mehawesh, M. (2014). Stages in Language Acquisition: A Case Study. English Language and Literature Studies, 4(4), 16-24. DOI: http://dx.doi. org/10.5539/ells.v4n4p16.

Schnitzer, M. and Krasinski, E. (1996). The Development of Segmental Phonological Production in a Bilingual Child: A Contrasting Second Case. Journal of Child Language. 23, 547-571. DOI: 10.1017/S0305000900008941.

Schnitzer, M. and Krasinski, E. (1994). The Development of Segmental Phonological Production in a Bilingual Child. Journal of Child Language. 21, 585-623.

Stempe, D. (1969). The Acquisition of Phonetic Representation. In R. Binnick et al. (eds.), Papers from the Fifth Regional Meeting of the Chicago Linguistic Society, 443-444. Chicago: Chicago.

Steriade, D. (2001). Directional Asymmetries in Place Assimilation: a Perceptual Account. In E. Hume and K. Johnson (eds.) Perception in Phonology, Academic Press. http://linguistics.ucla.edu/people/steriade/papers/ ICPHS2000.pdf.

Vogel, I. (1975). One System or Two: An Analysis of a Two-Year Romanian- English Bilingual's Phonology. Papers and Reports on Child Language Development. 9, 43-62.

Volterra, A. V. and Taeschner, T. (1978). The Acquisition and Development of Language by Bilingual Children. Journal of Child Language. 5, 331-326.

Yip, V. and Matthews, S. (2007). The Bilingual Child: Early Development and Language Contact. Cambridge: Cambridge University Press.

Yip, V. (2013). Simultaneous Language Acquisition. In F. Grosjean and P. Li (eds.), The Psycholinguistics of Bilingualism, 5-25. West Sussex: Wiley-Blackwell.

Younis, O. (2008). A Phonological Study of Child Utterances at the Age of Two. Buhuth Mustaqbaliya. 22, 7-23. 